\title{
Q uality of raw materials from different regions of Minas Gerais State utilized in ration industry
}

\author{
Paulo C. Coradi ${ }^{1}$, Adílio F. Lacerda Filho ${ }^{1}$ \& Evandro C. Melo ${ }^{1}$
}

\begin{abstract}
The present work aimed at evaluating the quality of raw materials destined for animal feed production, as well as the quality of corn produced in different areas of the $M$ inas $G$ erais State. The study was conducted in a feed mill for poultry, with production capacity of $1,000 \mathrm{t} \mathrm{d}^{-1}$. Samples of corn, soybean, flours, animal meals, and feed, during the year of 2008 were collected for analysis of moisture, acidity, peroxides, crude protein, ethereal extract, and physical classification of the corn for "type". The collection of samples, physical-chemical analysis and classification of corn according to "type" were performed at the Industrial Laboratory and at the Department of Agricultural Engineering of Federal U niversity of Viçosa. It was concluded that: raw materials meet the minimum demands of quality (with regards to physical-chemical and nutritional aspects); the corn grains and some by-products present high indexes of moisture and are subject to microbiological contamination during storage; the corn produced in the different areas of Minas Gerais State can be classified as "type 1" for commercialization.
\end{abstract}

Key words: corn, bran, flour

\section{Q ualidade de matérias-primas das diferentes regiões do estado M inas Gerais usadas na indústria de ração}

\section{RESU MO}

O bjetivou-se, com este trabalho, avaliar a qualidade das matérias-primas destinadas à indústria de ração e às rações processadas, além da qualidade do milho produzido nas diferentes regiões do estado de Minas de Gerais. 0 estudo foi conduzido em uma indústria de ração para aves, com capacidade de produção de $1,000 \mathrm{t} \mathrm{d}^{-1}$. Para as análises de teor de água, acidez, peróxidos, proteína bruta, extrato etéreo e classificação física do milho por "tipo" amostras de: milho, soja, farinhas de origem animal, farelos e rações, foram coletados durante o ano de 2008. A coleta de amostras, as análises físicoquímicas e a classificação do milho por "tipo", foram realizadas no laboratório da indústria e no Departamento de Engenharia Agrícola da U niversidade Federal de Viçosa (UFV). Concluiu-se que as matérias-primas atendem às exigências mínimas de qualidade quanto aos aspectos físico-químicos e nutricionais; os grãos de milho e alguns subprodutos apresentam índices de teor de água elevados e está sujeita a contaminação microbiológica, durante armazenamento; 0 milho produzido nas diferentes regiões do estado de Minas Gerais pode ser enquadrado no "tipo 1", para comercialização.

Palavras-chave: milho, farelo, farinha 


\section{INTRODUCTION}

Market differs worldwide in quality requirements for end product. However, it is possible to observe that importing countries are increasingly adopting preventive measures with regards to the quality of the products in the market. These countries justify their increased standards based on environmental issues, health and food safety concerns, and on international standards (Figueira et al., 2003).

The international standards are concerned with quality for animal ration and ingredients, protein composition and amino acids, fatty acids, minerals, vitamins and digestive energy of components and feed, related to the manufacturing processes. Among the ingredients for feed formulation for poultry, maize is the main raw material (60-80\% by mass). It is an important energy source. The importance of maize in nutrition is related to its nutritional properties (high starch content, protein, oils and vitamins), which make it one of the basic components of diet in humans and domestic animals (Figueira et al., 2003). Based on its use in ration manufacturing, maize is one of the most popular cereals produced, but its consumption is related to the demand of pork and poultry meat. In 2008, the world production of maize was approximately 700 million tons, and Brazil participated with $7.1 \%$ of the total. It is characterized as the third largest producer, after the United States and China. The achievement of high quality grains depends on several factors, such as species and variety characteristics, edaphoclimatic conditions during its development, harvest time and procedure, drying methods, and storage practices (Chowdhury \& Buchele, 1978). During harvest, the losses are the subject of many studies. Chowdhury \& Buchele (1978) observed an increase in grain losses in harvest when it is carried out with lower water content; however, Silva (1997) concluded that the mechanical damage on the seed quality and maize grains should increase with the use of higher water content during harvest. Water content is one of the most influential factors on mechanical damage of the variety and maturation stage observed during harvest. Chowdhury \& Buchele (1978) affirmed that the grains in mechanical harvesting are subject to mechanical impact, which may cause broken kernels, and falls, mainly when the water content of the grains are above $22 \%$ (w.b.).

Infections caused by fungi of the species Fusarium, Aspergillus, Penicillium, Cladosporium, Cephalosporium and Stenocarpella (Pinto, 2003) are the main causes of burnt grains, causing losses and reduction in quality (Elias et al., 2008). In addition, burnt grains are a risk to animal health, and can be contaminated by mycotoxins, causing economic losses for farmers by lowering the quality of the product (Munkvold et al., 1997). According to Brasil (1996) to have a quality product in the market requires that the maize has water content up to maximum of $14 \%$ (w.b.), impurities up to $1 \%$ of the sieve, with $3 \mathrm{~mm}$ sieves or up to $3 \%$ in sieve of $5 \mathrm{~mm}$, and a maximum of $6 \%$ of burnt grains. The presence of insects, fungi, toxins, seed toxicity, and pesticide residues must be avoided. The by-products such as rice meal, wheat and soybean, meat meal, bone, feathers, viscera, fats are also commonly used in feed formulation. Besides, the microingredients make the physico-chemical analysis important to evaluate the product's preservation (Keshavars \& Austic, 2004; Rostagno et al., 2005). Therefore, the present work aimed to evaluate the quality of raw materials in the Minas Gerais state intended for the ration industry, as well as the quality of the maize produced in different regions of the state.

\section{MATERIAL AND METHODS}

The work was conducted in a pellet feed industry for poultry. The sampling and physical-chemical analysis of raw material properties and feed and corn classification was carried out in the Industry Laboratory and at the Department of Agricultural Engineering of the Federal University of Viçosa (UFV).

\section{Collection and data analysis}

Verification of the raw material quality and feed production was carried out by sampling and physical-chemical analysis during the period of one year. The monthly average, standard deviation, and the variation coefficient for each product were calculated based on results obtained. The results were presented in graphics and compared with the quality standards set. The physical sampling and classification by "type" were held for maize, and for all suppliers of the regions of the Minas Gerais State. The minimum, maximum, and average data, the standard deviation and the variation coefficient were obtained. The maize quality was compared to other regions of the Minas Gerais state in accordance with the classification standards (Brasil, 1996).

\section{Sampling system}

The sampling of corn, sorghum, soybean, integrated extruded soybean, corn germ, rice bran, wheat and soybean meal, meat meal, bone meal, feathers meal, viscera and viscera oils was carried out in the receiving stage, before weighing and unloading. Feed samples were collected in dispatch silos, before the loading of bulk carrier trucks.

The bran sampling was performed in accordance with the instructions contained in AOAC (1990). Samples of $1 \mathrm{~kg}$ were removed for each $1,000 \mathrm{~kg}$ of product. Samples of $15 \mathrm{~kg}$ of meals were collected for every $100 \mathrm{t}$. In viscera oils, samples of $5 \mathrm{~kg}$ were collected for every $100 \mathrm{t}$, and in feed, samples of 45 $\mathrm{kg}$ for every $100 \mathrm{t}$ were collected. All the samples were homogenized, reduced, and packed in three routes with weights of $1 \mathrm{~kg}$ each, duly identified for analysis and certified according to the methodology described by AOAC (1990). For soybean, maize, and sorghum grains, sampling was performed in different points of the transport vehicle, and the number of points collected was established according to the vehicle size. For each sample $3 \mathrm{~kg}$ of product was removed. A sampling officer mechanical compound was used for the sampling process. The Decree $n^{\circ} .262$ of November 23, 1983 (Brasil, 1983) was used as reference for soybean grains, the Ordinance $\mathrm{n}^{\circ} .268$ of August 22, 1984 (Brasil, 1984), for grain sorghum, and the Decree $n^{\circ}$. 845 of November 8 (Brasil, 1996), for maize grains.

\section{Analysis of properties analysis of raw materials and feed}

The products, by-products, and feed sampled were submitted to physical-chemical analysis. For soybean grains and extruded, integrated soybeans, corn germ, rice bran, wheat 
bran and soybean meal analyses were carried out for water content, crude protein, ethereal extract, and total fiber. Analyses for water content, acidy index and peroxides were carried out for meat meal, bone meal, feather meal, viscera meal, viscera oils, and feed. The water content in the corn grains, soybean, and sorghum were determined by official incubator method, using $105 \pm 2{ }^{\circ} \mathrm{C}$, during $24 \mathrm{~h}$, with three replications, according to the recommendations contained in rules for seed analysis (Brasil, 1996). In products and by-products of animal origin and feed, the method described by AOAC (1990) was used. The same was done for the analyses of acidity, peroxides, total fiber, crude protein, and ethereal extract.

\section{Corn classification by type}

To analyze the physical quality of corn, sample homogenization and the weighing of $250 \mathrm{~g}$ were performed. This sample of work was passed in a sieve for the corn classification, with holes of $5 \mathrm{~mm}$ in diameter. Corn classification was performed according to the criteria described in the Administrative Rule $\mathrm{n}^{\circ}$. 11, of April 12, 1996, drawn up by the Ministry of Agriculture and Livestock Supply (Brasil, 1996). Products that exceeded the tolerance ceilings for defects established for Type 3 were framed as "below standard". Products in bad conservation status, with aspect of molds or fermentation, mixed with castor bean seed or other which might adversely affect the use of the product, or presented a strange odor were disqualified.

\section{RESULTS AND DISCUSSION}

Table 1 presents the relative frequency of the samples of nonstandard products. Figure 1A presents the average values of water content $(p>0.05)$ for flour of animal origin used in feed formulation. In these products, moisture below $9 \%$ was observed, a limit considered tolerable by AOAC (1990). Higher water contents could be a source for microbial growth, mainly of the Salmonellas species, causing deterioration to the products and also increasing the process of fat degradation. The Salmonella bacteria are frequently found in nature and, in addition to poultry, can infect human-beings, insects, fish, reptiles and mammals, causing a disease called salmonellosis. It may cause clinical or subclinical infection in poultry, which may remain as a reservoir and source of infection for humanbeings (Bellaver \& Zanotto, 2004).

The observed values of humidity, which are exceedingly low (mainly for meat meal and bone meal), may be related to high temperature during processing, causing reduction in availability of nutrients for animals (Bellaver \& Zanotto, 2004). Vegetable meals, soybean, sorghum and corn grains showed water content levels (Figures 1B, 1C and 1E), which were below the limit recommended (Burris, 1980; Elias et al., 2008; Faroni et al., 2009) for the preservation of products during storage. While for integrated and extruded soybean (Figure 1D), significant variations $(p>0.05)$ in water content were observed. The microbiological contamination of the products is linked directly with the environmental and product conditions. According to some authors (Moreno et al., 2006), water content levels above $11 \%$ (w.b.) generally increase the development of
Table 1. Relative frequency of products sampled below the standards quality of water content (WC), crude protein $(C P)$, ethereal extract (EE), crude fiber (CF), acidity, and peroxides during 2008, according to the Figures 1, 2, 3, 4 , and 5

\begin{tabular}{|c|c|c|c|c|c|c|}
\hline \multirow{3}{*}{ Products } & \multicolumn{6}{|c|}{ Frequency (\%) } \\
\hline & WCo & $\mathrm{CP}$ & EE & CF & \multirow{2}{*}{$\begin{array}{c}\text { Acidity } \\
\left(\mathrm{mgNaOHg}^{-1}\right)\end{array}$} & \multirow{2}{*}{$\begin{array}{l}\text { Peroxides } \\
\left(\text { meqkg }^{-1}\right)\end{array}$} \\
\hline & \multicolumn{4}{|c|}{$(\%)$} & & \\
\hline Corn germ ${ }^{a}$ & 0.0 & 11.1 & 0.0 & 7.4 & - & - \\
\hline Corn grains ${ }^{b}$ & $64.7^{*}$ & 67.4 & 12.3 & 66.1 & - & - \\
\hline Sorg. grains ${ }^{c}$ & 0.0 & 25.5 & 2.1 & 85.6 & - & - \\
\hline Soyb. grains ${ }^{d}$ & 23.7 & 38.9 & 26.4 & 10.7 & - & - \\
\hline Extr. soybean ${ }^{\mathrm{e}}$ & 18.4 & 26.6 & 22.2 & 8.3 & - & - \\
\hline Des. soybean ${ }^{f}$ & 55.8 & 57.1 & 12.5 & 6.8 & - & - \\
\hline Rice bran ${ }^{9}$ & 0.0 & 4.8 & 52.6 & 18.4 & - & - \\
\hline Wheat bran ${ }^{\mathrm{h}}$ & 0.0 & 5.5 & 23.7 & 16.5 & - & - \\
\hline Soybean meal & 14.7 & 5.3 & 6.4 & 3.7 & - & - \\
\hline Viscera mealj & 0.0 & - & - & - & 0.0 & 0.0 \\
\hline Feathers meal' & 13.7 & - & - & - & 0.0 & 5.4 \\
\hline Meat meal ${ }^{m}$ & 0.0 & - & - & - & 0.0 & 0.0 \\
\hline Bone meal $^{\mathrm{n}}$ & 0.0 & - & - & - & 0.0 & 0.0 \\
\hline Viscera oil ${ }^{0}$ & - & - & - & - & 0.0 & 0.0 \\
\hline Initial feed ${ }^{p}$ & 15.3 & - & - & - & 0.0 & 2.5 \\
\hline Growth feed ${ }^{9}$ & 12.5 & - & - & - & 0.0 & 0.0 \\
\hline Final feed ${ }^{r}$ & 12.9 & - & - & - & 2.1 & 68.7 \\
\hline
\end{tabular}

microorganisms for some products. Insects and fungi are among the main microorganism contaminants in storage. The fungi of Aspergillus flavus and parasiticus species are found in stored grains and develop easily with substrate moisture above $14 \%$ (w.b.), water activity higher than 0.70 , optimal temperature for growth between 35 and $38^{\circ} \mathrm{C}$, minimum between 8 and $15^{\circ} \mathrm{C}$ and maximum, between 40 and $45^{\circ} \mathrm{C}$ (RegitanoD’Arce et al., 1994; Rupollo et al., 2006).

The presence of fungi may encourage mycotoxin production in stored products. Aflatoxins are secondary metabolites, produced by some fungi strains of the genus Aspergillus, mainly the A. flavus and A. parasiticus species, which develop naturally in foodstuffs, and have been frequently found in corn, groundnut, bean, rice and wheat, cotton seed, grain sorghum, spices, feed, and fruits (Elias et al., 2008). The factors affecting the magnitude of toxicity in human-beings or animals that consume food or feed contaminated with mycotoxins are: the species, mechanism, action, and metabolism. Mycotoxins are generally carcinogenic and, when observed in excess, they are usually attacking the liver, kidneys, intestine, and lungs of animals and humans (Hussein \& Brasel, 2001).

\section{Acidity index and peroxides}

The formation of acidity and peroxides in animal products, oils, and animal feed occurs because of the presence of free fatty acids, which are formed by hydrolyzed fats present in the products. The lipase enzymes released by lipolytic bacteria hydrolize fats cause rancidity.

Therefore, acidity is often associated with bacterial contamination of the product, and may be accelerated by other factors resulting from oxidation, such as humidity, temperature, and oxygen (Bellaver \& Zanotto, 2004; Rostagno et al., 2005). 
A.

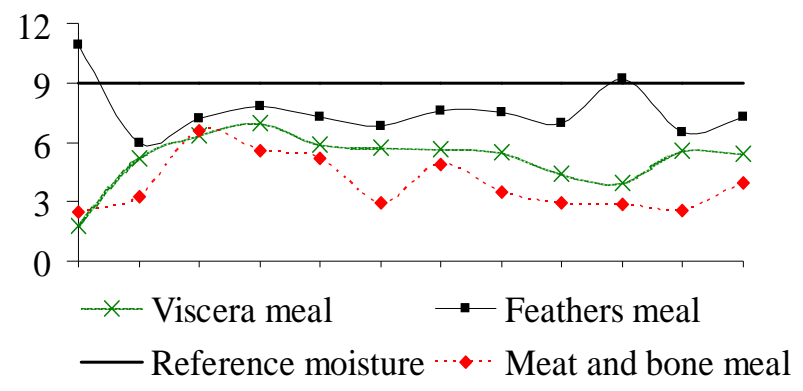

B.

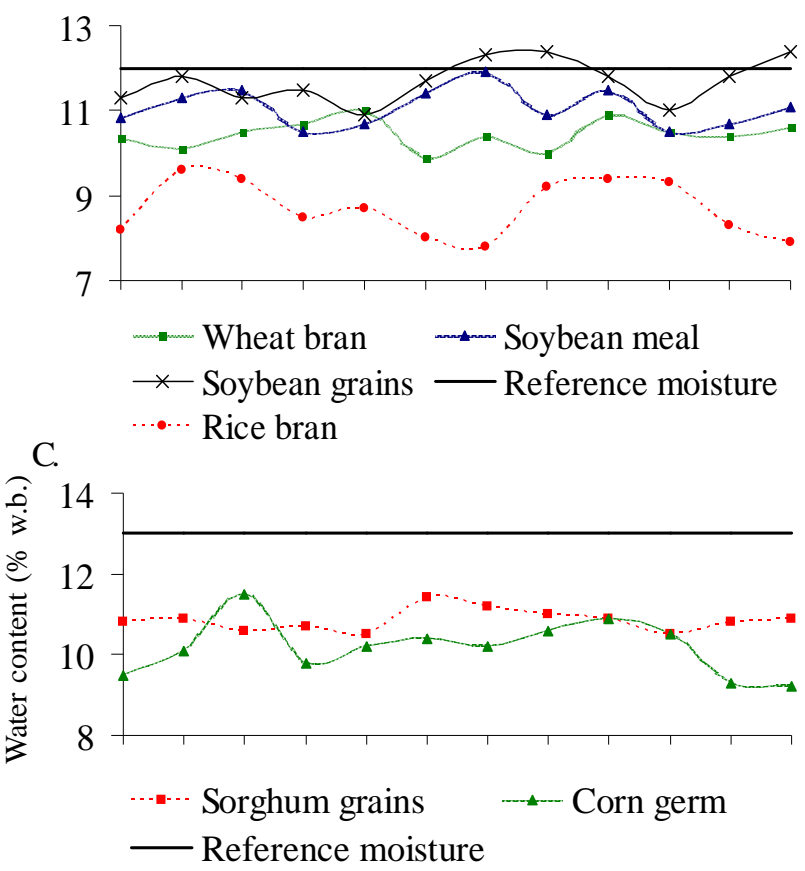

D.

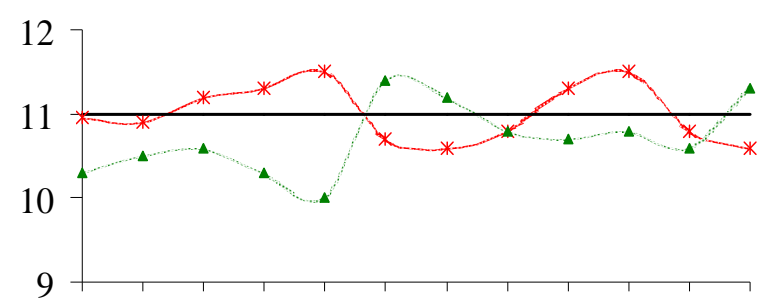

- *-- Integrated soybean $\quad \backsim-$ Extrused soybean

E

- Reference moisture

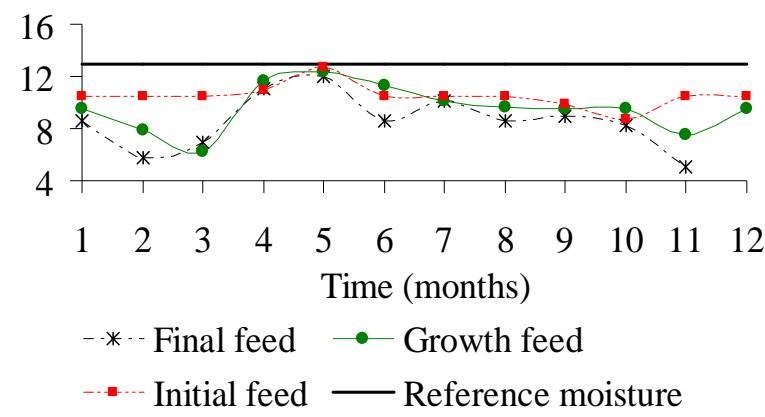

Figure 1 . W ater content for animal meal $(A)$, meals and soybeans (B), grains of sorghum and corn germ (C), integrated and extruded soybean (D), industrialized feed (E)
In the products assessed, the average values of acidity and peroxides $(p>0.05)$ obtained in animal meal, oils and feed during the evaluation period are presented in Figures 2A and 2B. In general, the acidity of the products assessed was less than 3.5 $\mathrm{mg} \mathrm{NaOH} \mathrm{g}^{-1}$, the value recommended by Rostagno et al. (2005). The peroxide index was above $10 \mathrm{meq} \mathrm{kg}^{-1}$ for the final feed. The high peroxide indexes in feed may have been due to the inadequate processing and storage of some by-products mainly used in the manufacture of viscera meal, meat meal, feather meal, bone meal, and viscera oils. The presence of peroxides leads to more free radicals, acetones, aldehydes, and alcohols, thus increasing toxicity. Animals which ingest such meal may be affected by muscular dystrophy, diatheses, necrosis, etc. (Rostagno et al., 2005).

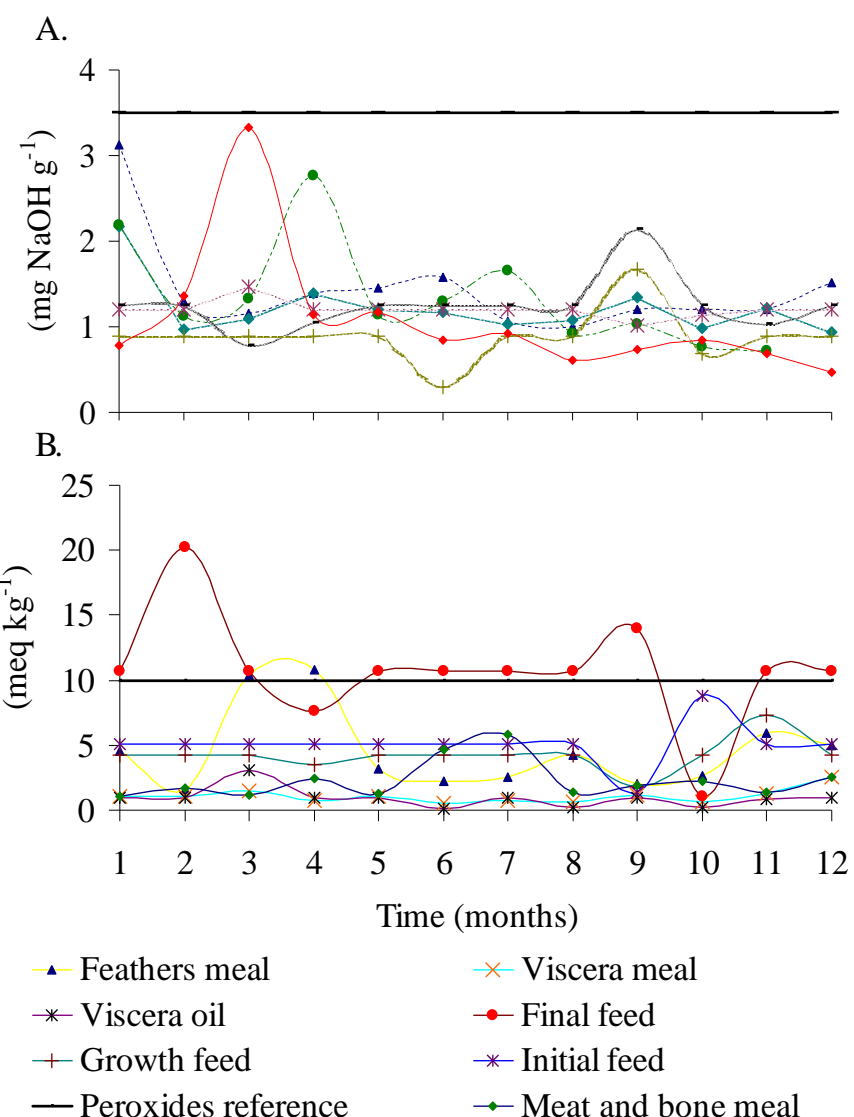

Figure 2. Acidity index for meals, oils and feed $(A)$, peroxides index to meal, oils and feed (B)

\section{Crude protein, ethereal extract and crude fiber}

The nutritional quality (protein, extract ethereal and crude fiber) of the raw material from Minas Gerais State was characterized and compared with the standards recommended by Rostagno et al. (2005) in Figures 3, 4, and 5. The analysis demonstrated that the products assessed comply with the standards required for use as ingredients in ration formulation. The nutritional values of the raw materials may vary according to the processing methods, climatic conditions and season, among other factors. The variety of raw materials offered for the minimum cost of formulation should be adequate for chickens. Limits for the formulation shall be imposed on ingredients that cause problems when used in excess. 

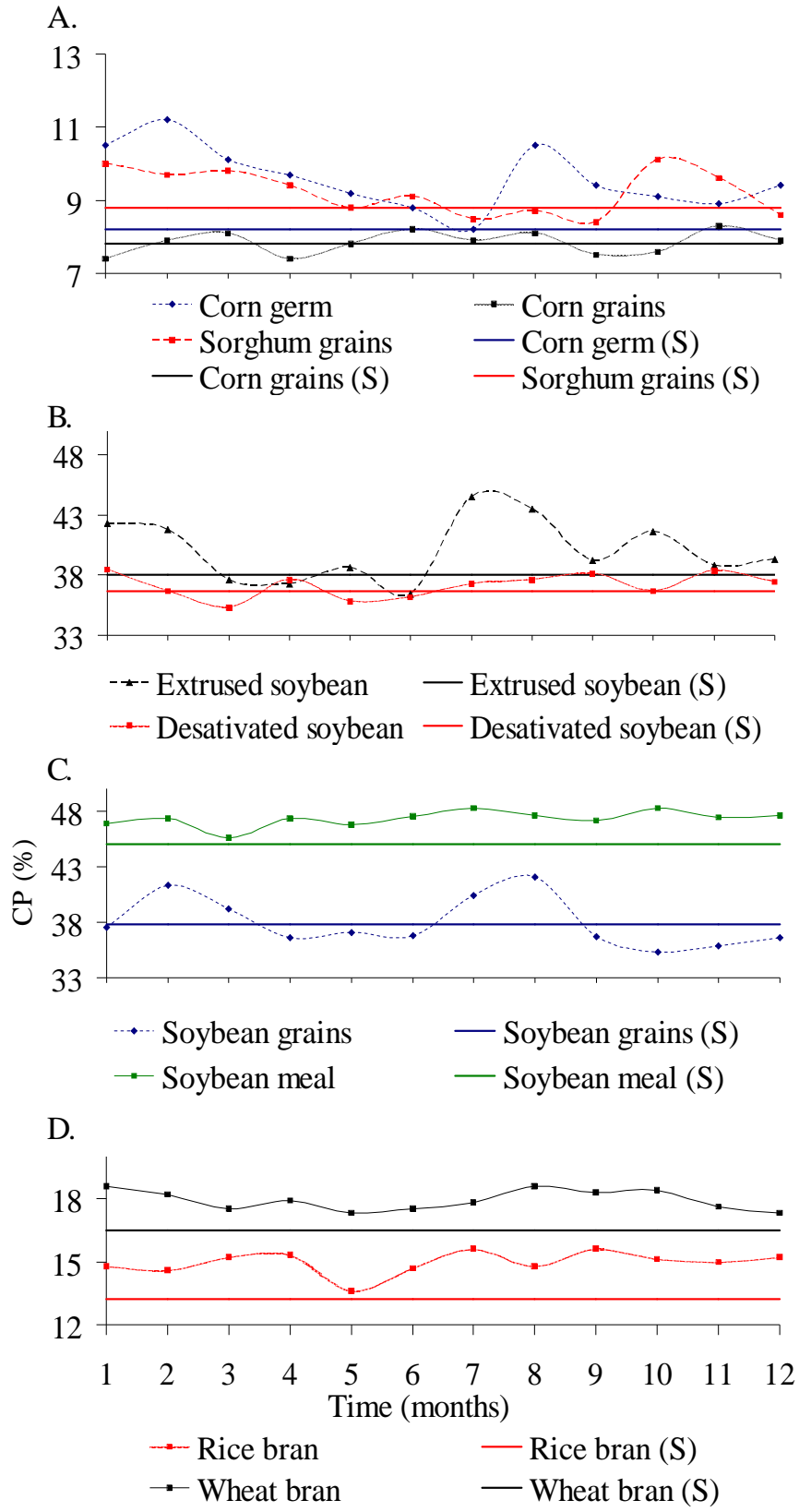

Figure 3. Crude protein - CP content in different meals

Proteins are important ingredients and which perform several functions in the body, such as building and maintaining tissues, hormones, and enzymes, acting as a secondary energy source, transporting and storing fats and minerals, participating in the production of sperm and eggs and transporting oxygen (Costa et al., 2004). Feed consumption is not necessarily controlled by feed protein level. An increase in feed consumption occurs with low crude protein, and if the protein level is exaggeratedly high or low, the fowl will best consume at an intermediate level (Keshavars et al., 2004; Costa et al., 2004). High levels of crude protein in feed increase the heat burden that is being dissipated, which may compromise the poultry's performance, while a reduction in protein levels results in decreasing the heat production and helping the poultry to maintain its energy balance in conditions of high temperatures (Morris, 2004).

Soybean meal with low protein may contain high levels of potassium which may lead to diarrhea, bad quality, and
A.

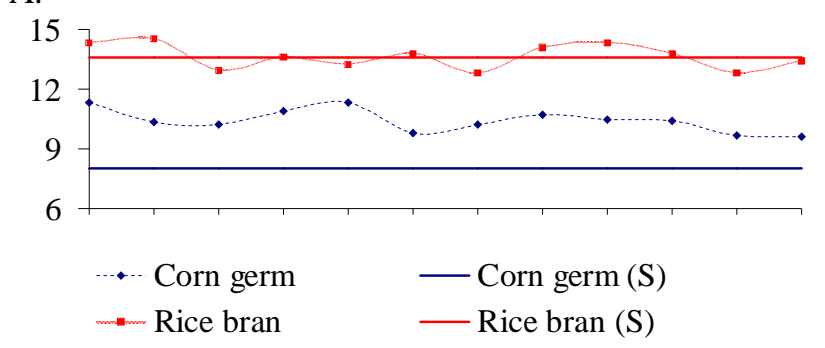

B.

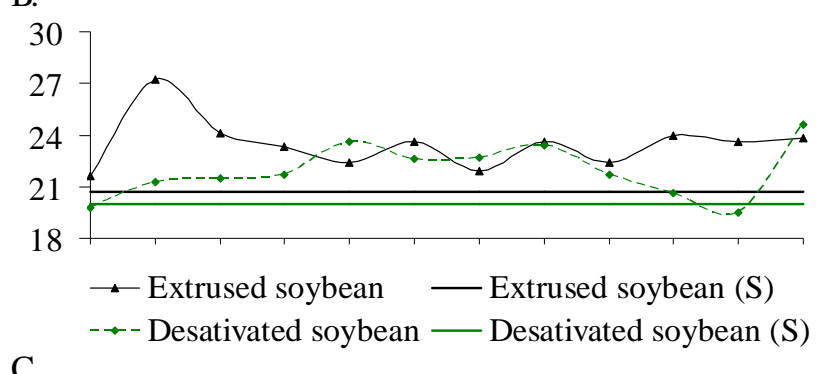

C.

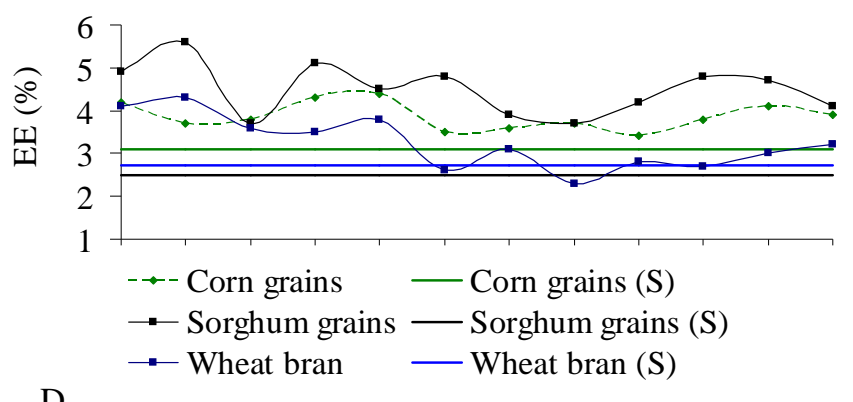

D.

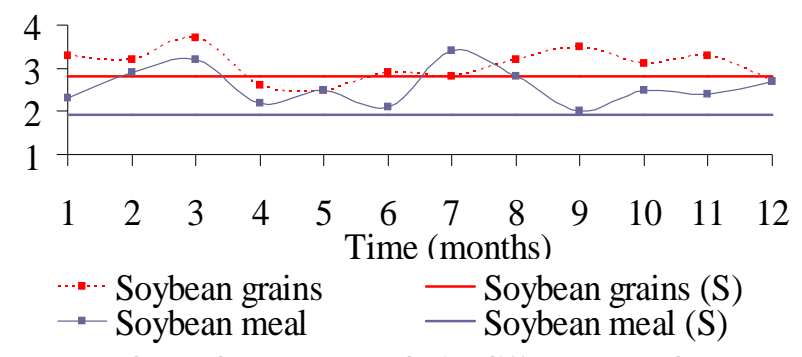

Figure 4. Ethereal extract - EE \% in different meals

subsequent depreciation of carcasses. The addition of soybean meal or soybean oil to a diet has beneficial effects, because it improves the digestibility of saturated fat (Rostagno et al., 2005). In general, the sorghum varieties presented higher contents of crude protein than corn (8.8 to 15\%), although it is less digestive.

Wheat bran presents good protein concentration $(15.52 \%$ in accordance with Rostagno et al. (2005). However, its addition to the diet of poultry is limited by high fiber concentration (9.66\% in accordance with Rostagno et al., 2005). Feed formulated with economically low cost ingredients are generally of low digestibility and palatability. In such cases the extract ethereal levels, crude fiber content, and high mineral are reduced (Roque et al., 2006). The contrary occurs when good quality ingredients are used (Roque et al., 2006). Crude fiber is important to maintain intestinal health, but the inclusion of vegetable meals in excess may raise the crude fiber level above the recommended levels and compromise the digestion and absorption of organic matter and energy in many species, including dogs (Earle et al., 1998). 
A.

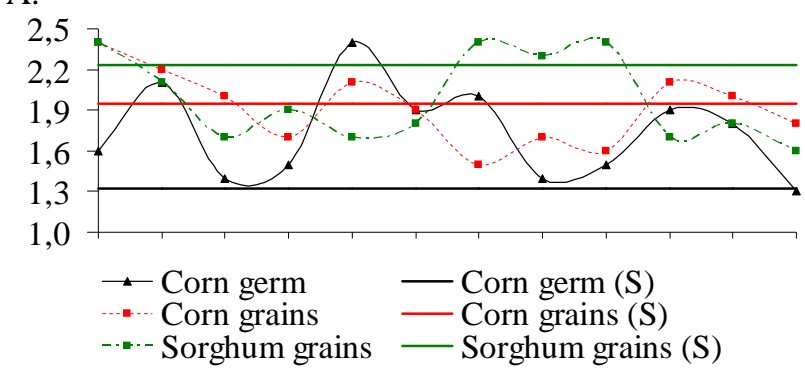

B.

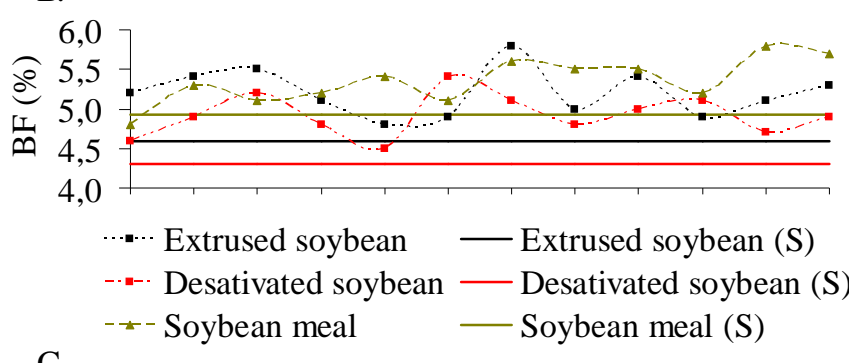

C.

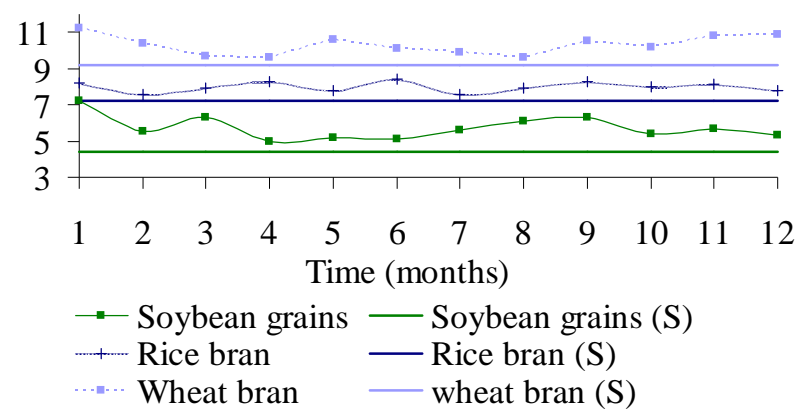

Figure 5. Crude fiber - BF in different meals

Fibers work only in the fecal cake and maintenance of transit in the gastrointestinal tract, promoting an increase in bowel movements, dilution of energy and a decrease in the digestibility of nutrients. Roque et al. (2006) reports that, with fiber current classification, the idea of energy dilution and decreasing digestibility of nutrients is not totally wrong, since an excess of undigestible fiber could cause such effects. At the meantime, soluble physiological fibers result in several benefits, such as modulation of gastrointestinal motility, increase in mass, volume and consistency of feces and reduction of diarrhea by increasing water absorption (Roque et al., 2006).

\section{Corn classification by type in the different regions of Minas Gerais State}

Table 2 presents the relative frequency of the samples of nonstandard products while the Figure 6 (A, B, C and D) present the physical analyses of water content, strange matter, impurities and fragments, damaged, burned, moldy grains and sprouted kernels, for the corn grains produced in different regions of Minas Gerais State. The mean water content levels (Figure 3B) for all regions varied between 14 and 19\% (w.b.), which is above the pattern of corn classification (Brasil, 1996). To meet the transport logistics and the production system of the feed mill, it is important to have a good system for receiving, drying and storing products. It was observed that corn from distant regions comes with lower water content levels, while for the corn grains of closer proximity, almost all the drying is carried out in the facility itself. The high water content levels for the products analyzed may mean contamination by fungi. Dilkin et al. (2000) found contamination in 23.6, 57.1 and $14.3 \%$ of Aspergillus sp., Fusarium sp. and Penicillium sp., respectively, in five newly-harvested corn hybrid grains, with $18 \%$ of water content in Santa Maria, Rio Grande do Sul State. On the other hand, corn harvested with water content lower than $18 \%$ tends to lose dry mass in the field, which is necessary for breathing (Dilkin et al., 2000).

Table 2. Relative frequency of corn sampled below of the standards of physical classification during 2008 to according with the Figure 6

\begin{tabular}{lcccc}
\hline \multirow{2}{*}{ Regions $^{1}$} & \multicolumn{4}{c}{ Frequency $^{2}(\%)$} \\
\cline { 2 - 5 } & WC & SMIF & D & BMSG \\
Zona da Mata $^{\mathrm{a}}$ & 77.3 & 0.0 & 0.0 & 0.0 \\
Triângulo Mineiro $^{\mathrm{b}}$ & 64.4 & 0.0 & 0.0 & 0.0 \\
Southern and Southwestern Minas $^{\mathrm{c}}$ & 62.7 & 0.0 & 0.0 & 0.0 \\
Western Minas $^{\mathrm{d}}$ & 53.1 & 0.0 & 0.0 & 0.0 \\
Northwestern Minas $^{\mathrm{e}}$ & 48.6 & 0.0 & 0.0 & 0.0 \\
${\text { Belo Horizonte Metropolitan } \text { area }^{\mathrm{f}}}^{\mathrm{C}}$ & 68.2 & 0.0 & 0.0 & 0.0 \\
Campo das Vertentes $^{\mathrm{g}}$ & 78.9 & 0.0 & 0.0 & 0.0 \\
\hline
\end{tabular}

${ }^{1}$ Number of corn suppliers per region of the Minas Gerais State: ${ }^{\mathrm{a}}(71),{ }^{b}(23),{ }^{\mathrm{c}}(49),{ }^{d}(7),{ }^{\mathrm{e}}(16)$, ${ }^{f}(6),{ }^{g}(39)$. Total number of samples: $a=213, b=69, c=147, d=21, e=48, f=18, g=117$ 2 WC - Water content; SMIF - Strange matter; impurities and fragments; D - Damaged; BMSG Burnt moldy and sprouted grains

Furthermore, the grains may suffer major injuries during threshing, causing broken endosperm and scarifi pericarp, or even the rupture of the endosperm, exposing its content to fungi and insects. This negatively affects the potentiality of storage with the reduction in the specific mass and mycotoxin formation (Radünz et al., 2006). Santin et al. (2004), evaluating the effect of maize harvest delay related to burnt grains and pathogenic fungi, found that the extended permanence of maize cobs in the plant, after physiological maturity, influenced the reduction of the incidence of Fusarium moniliforme, following the reduction of water content in the grains.

On the other hand, the authors observed that there was an increased incidence of $F$. graminearum and of Aspergillus and Penicillium, when the grains were collected with lower water content. All regions analyzed showed low rates of strange matter, impurities, and fragments (Figure 6B). The lowest results were observed in the Zona da Mata region, and the highest, in the Northwestern Minas region. It was also observed that the damaged indexes (Figure 6C) in the Zona da Mata region showed lower values, while in the Belo Horizonte metropolitan region, Western Minas, and Northwestern Minas, the indexes were higher. Figure 6D presents the percentage of burnt, moldy, and sprouted grains for the different regions analyzed. In general, all regions were characterized by average indexes below $3 \%$, which means type 1 , according to the requirements of the official corn classification (Brasil, 1996). However, the low burnt, moldy, and sprouted grains indexes do not meet the quality demands of the feed industry. The burned grains are reflexes mainly by fungi present in the field. This means that there is a possibility for mycotoxin production, such as aflatoxins, zearalenone, fumonisins, T-2 toxins, and others, which could impair the quality of the feed produced (Nesci et al., 2003; Kumar et al., 2008). 
A.

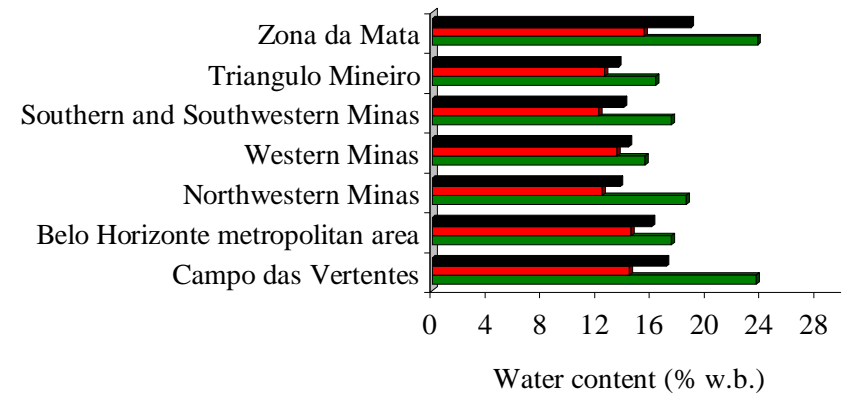

B.

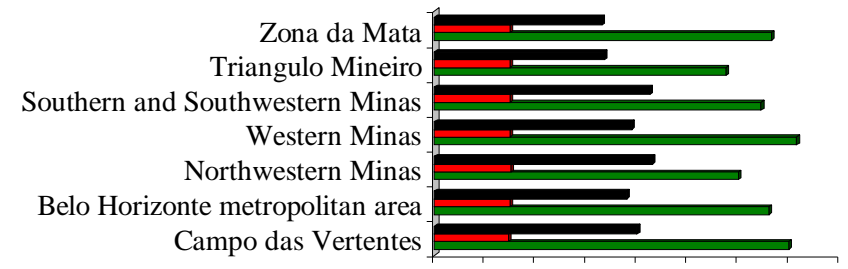

$\begin{array}{lllllllll}0,0 & 0,2 & 0,4 & 0,6 & 0,8 & 1,0 & 1,2 & 1,4 & 1,6\end{array}$ Strange matter, impurities and fragments $(\%)$

C.

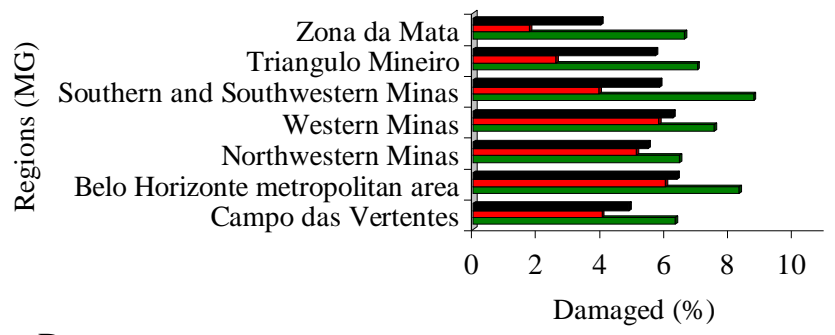

D.

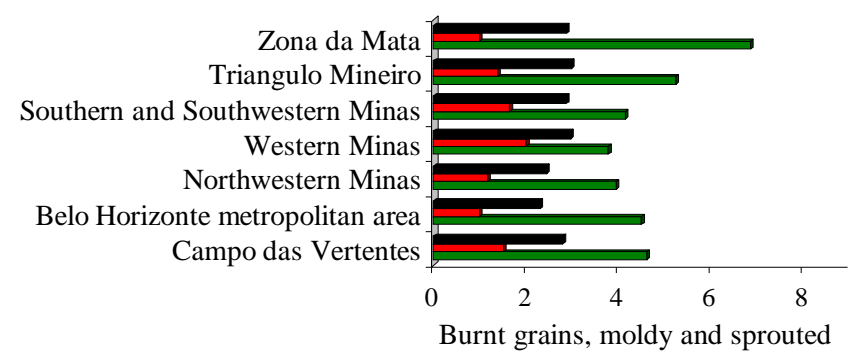

(\%)

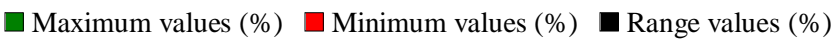
Figure 6. W ater content (A), percentage of strange matter, impurities, and fragments (B), percentage of damaged grains $(C)$, percentage of burnt, moldy, and sprouted grains (D) in corn from different regions of M inas Gerais State

Qualitative losses by burnt grains are a reason for product devaluation and a threat to animal and human health. That is why it is necessary for the feed industry to establish its referential standard, and be more stringent than the commercial classification.

\section{Conclusions}

1. The various raw materials produced in the Minas Gerais State used in the animal feed industry attend the minimum physical-chemical and nutritional quality requirements.
2. Corn grains and certain products of different regions of the Minas Gerais State reach the feed industry with high water content and are subject to microbiological contamination during storage, according to the quality standards established by the Decree $n^{\circ}$. 11, of April 12, 1996.

3. The corn produced in different regions of Minas Gerais State, although presenting low quality to be used in feed industry may be ranked as "type 1" for marketing.

\section{ACKNOWLEDGEMENTS}

The authors would like to thank the CAPES Foundation (Brazilian Ministry of Education), Department of the Agricultural Engineering and Federal University of Viçosa for the financial support.

\section{LITERATURE CITED}

AOAC - Association of Official Analytical Chemists. Official methods of analysis of the Association of Official Analytical Chemists. 15.ed. Washington: AOAC 1990, 1298p.

Bellaver, C.; Zanotto, D. L. Parâmetros de qualidade em proteínas e gorduras de origem animal. In: Conferência APINCO de Ciência e Tecnologia Avícola, 2004, Campinas. Anais...Campinas: FACTA, 2004. CD Rom.

Brasil. Portaria $n^{\circ} .262$. Normas de qualidade para classificação e comercialização da soja em grãos. Dário Oficial, Brasília, $1^{\circ}$ de janeiro, 1983.

Brasil. Portaria n. 268. Normas de identidade, qualidade, apresentação e embalagem do Sorgo. Dário Oficial, Brasília, 22 de agosto 1984.

Brasil. Portaria n.845. Estabelecem as especificações para a padronização, classificação e comercialização interna do milho. Diário Oficial, Brasília, n. 787, p.19756, 12 abril 1996, Seção 1.

Burris, J. S. Maintenance of soybean seed quality in storage as influenced by moisture, temperature and genotype. Iowa State Journal of Research, v.54, p.377-379, 1980.

Chowdhury, M. H.; Buchele, W. F. The nature of corn kernel damage inflicted in the shelling crescent of grain combines. Transactions of the ASAE, v.21, p.610-614, 1978.

Costa, F. G. P.; Souza, H. C.; Gomes, C. A. V.; Barros, R. L.; Brandão, P. A.; Nascimento, G. A. J.; Santos, A. W. R.; Amarante Junior, V. S. Níveis de proteína bruta e energia metabolizável na produção de qualidade dos ovos de poedeira da linhagem Lohmann Brown. Ciência e Agrotecnologia, v.28, p.1421-1427, 2004.

Dilkin, P.; Mallmann, C. A.; Santurio, J. M.; Hickmann, J. L. Classificação macroscópica, identificação da microbiota fúngica e produção de aflatoxinas em híbridos de milho. Ciência Rural, v.30, p.137-141, 2000.

Earle, K. E.; Kienzle, E.; Opitz, B.; Smith, P. M.; Maskell, I. E. Fiber affects digestibility of organic matter and energy in pet foods. Journal of Nutrition, v.128, 1998. p.2798-2800. 
Elias, M. C.; Dionello, R. G.; Forlin, F. J.; Oliveira, M.; Gelain, J.; Peter, M. Z. Avaliação do uso de ácidos orgânicos na conservação de grãos de sorgo (Sorghum bicolor L. Moench) durante o armazenamento. Semina: Ciências Agrárias, v.29, p.35-46, 2008.

Faroni, L. R. A.; Alencar, E. R. D; Paes, J. L.; Costa, A. R.; Roma, R. C. C. Armazenamento de soja em silos tipo bolsa. Revista Brasileira de Engenharia Agrícola e Ambiental, v.29, p.91100, 2009.

Figueira, E. L. Z.; Coelho, A. R.; Ono, E. Y. S.; Hirooka, E. Y. Milho: riscos associados à contaminação por Fusarium verticillioides e fumonosina. Semina. Ciências Agrárias, v.24, p.359-378, 2003.

Hussein, S. H.; Brasel, J. M. Toxicity, metabolism and impact of micotoxins on humans e animals. Toxicology, v.167, p.101134, 2001.

Keshavars, K.; Austic, R. E. The use of low protein, low phosphorus, amino acid - And phytase - Supplement diets on laying hen performance and nitrogen and phosphorus extretion. Poultry Science, v.83, p.75-83, 2004.

Kumar, V.; Basu, M. S.; Rajendran, T. P. Mycotoxin research and mycoflora in some commercially important agricultural commodities. Crop Protection, v.27, p.891-905, 2008.

Moreno, M. E.; Jimenez, A. S.; Vazquez, M. E. Hermetic storage system preventing the proliferation of Prostephanus truncatus Horn and storage fungi in maize with different moisture contents. Postharvest Biology and Technology, v.39, p.321-326, 2006.

Morris, T. M. Nutrition of chicks and layers. World's Poultry Science Association, v.60, p.5-12, 2004.

Munkvold, G. P.; Hellmich, R. L.; Showers, W. B. Reduced fusarium ear rot and symptomless infection in kernels of maize genetically engineers of European corn borer resistance. Phytopathology. v.87, p.1071-1077, 1997.
Nesci, A.; Rodriguez, M.; Etcheverry, M. Control of Aspergillus growth and aflatoxin production using antioxidants at different conditions of water activity and $\mathrm{pH}$. Journal of Applied Microbiology, v.95, n.2, p.279-287, 2003.

Pinto, N. F. J. A. Incidência de grãos ardidos em diferentes tipos de milho. Summa Phytopathologica, v.29, p.63-67, 2003.

Radünz, L. L.; Dionello, R. G.; Elias, M. C.; Barbosa, F. F. Influência do método de armazenamento na qualidade física e biológica de grãos de milho. Revista Brasileira de Armazenamento, v.31, p.136-143, 2006.

Regitano-D'Arce, M. A. B.; Rauenmiguel, A. M. O.; Casagrande, J. R. R.; Marcos, E. A.; Plonis, G. Time of harvesting and storage of soybeans - Influence on oil quality. Grasas Y Aceites, v.45, p.237-240, 1994.

Roque, N. C.; José, V. A.; Aquino, A. A.; Alves, M. P.; Saad, F. M. O. B. Utilização da fibra na nutrição de cães. Boletim Agropecuário, n.70, p.1-13, 2006.

Rostagno, H. S.; Albino, L. F. T.; Donzele, J. L. Tabelas brasileiras para suínos e aves: composição de alimentos e exigências nutricionais. 2.ed. Viçosa: UFV, 2005. 186p.

Rupollo, G.; Gutkoski, L. C.; Martins, I. R.; Elias, M. C. Efeito da umidade e do período de armazenamento hermético na contaminação natural por fungos e a produção de micotoxinas em grãos de aveia. Ciências Agrotécnicas, v.30, p.118-125, 2006.

Santin, J. A.; Reis, E. M.; Matsumura, A. T. S.; Moraes, M. G. Efeito do retardamento da colheita de milho na incidência de grãos ardidos e de fungos patogênicos. Revista Brasileira de Milho e Sorgo, v.3, p.182-192, 2004.

Silva, A. A. L. Desenvolvimento de um índice para avaliação de danos mecânicos em grãos de milho. Engenharia na Agricultura, v.5, p.244-253, 1997. 